\title{
Analisa Kemampuan Perawat dalam Mengklasifikasi Pasien Cedera Kepala Berdasarkan Nilai Glasgow Coma Scale (GCS)
}

\author{
${ }^{1}$ R. Meilando*, \\ ${ }^{1}$ Program Studi Ilmu Keperawatan, STIKES Citra Delima Bangka Belitung \\ Email : riskimeilando446@gmail.com
}

\section{Kata kunci : \\ Cedera Kepala,}

GCS,

Kemampuan Perawat.

\section{Keywords :}

Head Injury,

GCS,

The Ability Of Nurses.

Info Artikel:

Tanggal dikirim:

30 Mei 2020

Tanggal direvisi:

14 Juni 2020

Tanggal diterima :

29 Juni 2020

DOI Artikel:

10.33862/citradelima. v4i1.107

Halaman: $66-73$

\begin{abstract}
Abstrak
Cedera kepala merupakan penyebab utama kematian, angka mortalitas dan morbiditas cedera kepala ini mendekati sepertiga penyebab kematian pada pasien dengan multitrauma di berbagai Negara khususnya Indonesia. Data di RSUD Depati Hamzah Kota Pangkalpinang, Pada tahun 2015 jumlah total angka kejadian cedera kepala sebanyak 200 kasus, Pada tahun 2016 jumlah total angka kejadian cedera kepala sebanyak 262 kasus, Dan pada tahun 2017 jumlah total angka kejadian cedera kepala sebanyak 197 kasus. Tujuan penelitian ini adalah untuk menganalisa kemampuan perawat dalam mengklasifikasi pasien cedera kepala berdasarkan nilai GCS di IGD RSUD Depati Hamzah Kota Pangkalpinang tahun 2018. Jenis penelitian ini adalah penelitian deskriptif dengan pendekatan kualitatif. Sumber informan sebanyak 4 orang perawat pelaksana, 1 orang Kepala ruangan, 1 orang dokter, dan 1 Kasi Keperawatan. Pengumpulan data melalui wawancara mendalam. Hasil penelitian menunjukan bahwa perawat di IGD RSUD Depati Hamzah memiliki pengetahuan yang cukup baik, perawat melakukan tindakan sesuai dengan SOP (Standart Operasional Prosedur) yang ada, perawat minimal harus tersertifikasi pelatihan BTCLS, dan tidak ada supervisi di IGD RSUD Depati Hamzah Kota Pangkalpinang.Saran penelitian ini perlu adanya penyampaian sosialisasi tentang SOP kepada pegawai di IGD sehingga semua pegawai di IGD baik dokter ataupun perawat tau mengenai hal tersebut dan perlu adanya pengaktifan kembali sistem supervisi yang ada dirumah sakit, dan perlu adanya peningkatan pengetahuan dan keahlihan SDM melalui penambahan kuota pelatihan BTCLS.
\end{abstract}

\section{Analysis of Ability of Nurses in Classifying Patients of Head Injury Based on the Value of the Glasgow Coma Scale (GCS)}

\begin{abstract}
Head injury is the leading cause of death, mortality and morbidity figures a head injury was nearly a third cause of death in patients with multitrauma in different countries especially Indonesia. Data on Hospitals Depati Hamzah City Pangkalpinang, in 2015 the total number events head injury by as much as 200 cases in the year 2016 total number events head injury as much as 262 cases, and in 2017 the amount of the total figures for the incidence of head injury as many as 197 cases. The purpose of this research is to analyze the ability of nurses in classifying patients of head injury based on the value of the GCS in IGD Hospitals Depati Hamzah City Pangkalpinang year 2018. Type of this research is descriptive research with qualitative approach. The source of the informant as much as 4 people managing nurses, 1 Head, 1 doctor and 1 person Kasi nursing. The collection of data through in-depth interviews. Results of the study showed that nurses in hospitals IGD Depati Hamzah has quite a good knowledge, nurses take action in accordance with SOP (Standard Operational procedures), the nurse must be at least certified training BTCLS, and not There is supervision at IGD Hospitals Depati Hamzah City Pangkalpinang.This research is need for advice of delivery of dissemination of SOP to the clerk in the IGD so that all employees in the good doctor's or nurse's IGD know about it and the need for reactivation of the existing supervision systems at home sick, and need an increase in knowledge and Human resource through the addition quota BTCLS training.
\end{abstract}




\section{PENDAHULUAN}

Cedera kepala adalah kejadian yang mengakibatkan kerusakan morfologi dari struktur kepala manusia oleh adanya suatu besaran kekuatan. Selain cacat fisik, cedera kepala juga dapat menimbulkan cacat mental yang bisa bersifat menetap ataupun sementara. Hal tersebut berkaitan dengan gangguan pada struktur luar dan dalam dari kepala manusia (Mardjono, 2009).

Pemeriksaan klinis yang biasa digunakan untuk mempermudah mendiagnosa cedera kepala adalah pemeriksaan nilai Glasgow Coma Scale (GCS) yang dikelompokkan menjadi cedera kepala ringan, cedera kepala sedang, dan cedera kepala berat. Nyeri yang menetap atau setempat, biasanya menunjukan adanya fraktur (Smeltzer \& Bare 2002). Cedera kepala merupakan penyebab utama kematian, angka mortalitas dan morbiditas cedera kepala ini mendekati sepertiga penyebab kematian pada pasien dengan multitrauma. Cedera kepala menyumbang sekitar 52.000 atau $40 \%$ dari total kematian yang diakibatkan cidera akut (Syet $e t$ al, 2007).

Setiap tahun diperkirakan terdapat 1,5 juta kasus cedera kepala dari jumlah tersebut 230.000 pasien memerlukan dirumah sakit dan dapat bertahan hidup. 80.000-90.000 pasien mengalami kecacatan permanen dan 50.000 pasien meninggal dunia (Thurman et al, 2007).

Insiden cedera kepala secara global mengalami peningkatan seiring bertambahnya peningkatan penggunaan kendaraan bermotor. Diperkirakan pada tahun 2020 kecelakaan lalu lintas menyebabkan cedera kepala menjadi penyebab penyakit dan trauma ke - 3 terbanyak didunia pada era globalisasi dimana kemajuan teknologi semangkin berkembang khususnya dalam bidang transportasi sebagai kebutuhan sekunder yang utama, akibat aktifitas ekonomi, sosial, dan sebagainya, mengakibatkan peningkatan jumlah dan jenis kendaraan bermotor, hal ini berdampak pada peningkatan kasus kecelakaan bermotor yang menimbulkan korban jiwa (WHO, 2014)

Sedangkan di Indonesia Cedera kepala menempati peringkat ke -8 dari 10 besar penyakit rawat inap di seluruh rumah sakit Indonesia pada tahun 2010, yaitu sebesar 19.381 kasus ( Profil data kesehatan Indonesia Tahun 2010, Depkes Indonesia ). Penyebab cedera kepala adalah para pengguna kendaraan bermotor roda dua terutama bagi yang tidak memakai helm. Hal ini juga menjadi tantangan sulit dikarnakan diantara mereka datang dari golongan ekonomi menengah kebawah sehingga secara sosio ekonomi cukup sulit untuk memperoleh pelayanan kesehatan. Dengan alasan itulah angka kematian cedera kepala mencapai 39\% per tahunnya (Arifin, 2013).

Sedangkan data di Provinsi Kepulauan Bangka Belitung pada tahun 2007, menunjukanrata-rata prevalensi kejadian cedera di 7 Kabupaten/Kota sebesar 7,6 dengan penyebab paling tinggi terjadinya cedera disebakan karna terjatuh dan untuk rata-rata kejadian cedera kepala sebanyak 13,1 1 (Riset Kesehatan Dasar, 2007)

Data di 2 rumah sakit yang berada di Kota Pangkalpinang yaitu RS Bhakti Timah Pangkalpinang dan RSUD Depati Hamzah Kota Pangkalpinang menunjukan angka kejadian cedera kepala yang berbeda.

Data di RS Bhakti Timah Pangkalpinang, Pada Tahun 2015 total kejadian cedera kepala sebanyak 438 kasus, pada tahun 2016 total kejadian cedera kepala sebanyak 378 kasus, dan pada tahun 2017 total kejadian cedera kepala sebanyak 328 kasus (Rekam Medis RS Bhakti Timah Pangkalpinang, 2017).

Data di RSUD Depati Hamzah Kota Pangkalpinang, Pada tahun 2015 jumlah total angka kejadian cedera kepala sebanyak 200 kasus yang terbagi atas : Cedera kepala ringan 134 kasus (67\%), Cedera kepala sedang 26 kasus (13\%), dan cedera kepala berat 40 kasus (20\%). Pada tahun 2016 jumlah total angka kejadian cedera kepala sebanyak 262 kasus yang terbagi

http://jurnalilmiah.stikescitradelima.ac.id/index.php/JI Vol.4,No.1, Juli 2020 
atas : Cedera kepala ringan 213 kasus $(81,3 \%)$, Cedera kepala sedang 30 kasus $(11,45 \%)$, dan Cedera kepala berat 19 kasus (7,25\%). Dan pada tahun 2017 jumlah total angka kejadian cedera kepala sebanyak 197 kasus yang terbagi atas : cedera kepala ringan 163 kasus $(82,74 \%)$, cedera kepala sedang 18 kasus $(9,13 \%)$, dan cedera kepala berat 16 kasus $(8,12 \%)$.(Rekam medis RSUD Depati Hamzah, 2017).

RSUD Depati Hamzah kota Pangkalpinang memiliki Stadard Operational Prosedur (SOP) dalam penanganan pasien cedera kepala yang telah ditetapkan oleh Direktur RSUD Depati Hamzah Kota Pangkalpinang pada tahun 2009.

Dari hasil wawancara dan observasi pada tanggal 29 Maret sampai 2 April 2017 terhadap 5 orang perawat di IGD RSUD Depati Hamzah Kota Pangkalpinang tentang penanganan pasien cedera kepala, 3 perawat (60\%) paham mengenai klasifikasi pasien berdasarkan nilai Glasgow Coma Scale (GCS), 3 perawat (60\%) sudah pernah megikuti pelatihan BTCLS sedangkan 2 (40\%) perawat lainnya sertifikasi BTCLS sudah lewat dari 5 tahun, 3 perawat (60\%) melakukan tindakan sesuai dengan Standard Operational Prosedur (SOP), dan 5 perawat $(0 \%)$ mengatakan bahwa tidak adanya supervisi yang dilakukan oleh Kasi Keperawatan.

Sesuai dengan data diatas, maka peneliti tertarik untuk meneliti kasus cedera kepala degan judul "Analisa Kemampuan Perawat Dalam Mengklasifikasi Pasien Cedera Kepala Berdasarkan Nilai Glasgow Coma Scale (GCS)".

\section{METODE}

Desain penelitian yang digunakan adalah penelitian deskriptif dengan pendekatan kualitatif. Penelitian ini dimaksudkan untuk menggali informasi atau data sebanyak-banyaknya memalui metode wawancara mengenai analisa kemampuan perawat dalam mengklasifikasi pasien cedera kepala berdasarkan nilai Glasgow Coma Scale.

Metode penelitian kualitatif sering disebut juga sebagai metode penelitian naturalistic karena penetitiannya dilakukan pada kondisi yang alamiah, disebut juga sebagai etnograpi, karena pada awalnya metode ini lebih banyak digunakan untuk penelitian bidang antropologi budaya, disebut metode kualitatif karena data yang dikumpulkan dan analisanya lebih bersifat kualitatif (Sugiyono, 2011)

Informan dalam penelitian kualitatif adalah orang yang memahami informasi dari objek penelitian. Informan yang dipilih harus memiliki kriteria agar informasi yang didapatkan bermanfaat untuk penelitian yang dilakukan. Informan yang digunakan dalam penelitian ini berjumlah 7 orang dengan menggunakan tekhnik purposive sampling yaitu didasarkan pada suatu pertimbangan tertentu yang dibuat oleh peneliti sendiri (Notoadmodjo, 2010).

Informan penelitian utama adalah 4 orang perawat pelaksana sedangkan informan pendukung adalah 1 orang dokter, 1 orang kepala ruangan dan 1 orang kepala bidang keperawatan. Informan pendukung dipilih berdasarkan banyaknya informasi yang mereka miliki, kriteria Inklusi dan Ekslusi.

Tabel 1 Kriteria Inklusi dan Eklusi

\begin{tabular}{lr}
\hline \multicolumn{1}{c}{ Inklusi } & Eklusi \\
\hline 1. Perawat yang bekerja & 1. Tidak bersedia \\
di IGD RSUD Depati & menjadi informan. \\
Hamzah Kota & 2. Berpindah tugas saat \\
Pangkalpinang. & dilakukan penelitian. \\
2. Dokter yang bekerja di & \\
IGD RSUD Depati & \\
Hamzah Kota & \\
Pangkalpinang. & \\
3. Bersedia menjadi & \\
informan. & \\
4. Masa kerja $>1$ tahun. \\
5. Pendidikan minimal \\
D3.
\end{tabular}

http://jurnalilmiah.stikescitradelima.ac.id/index.php/JI Vol.4,No.1, Juli 2020 


\section{HASIL DAN PEMBAHASAN}

Hasil analisa pengetahuan perawat dengan kemampuan mengklasifikasi pasien cedera kepala berdasarkan nilai Glasgow Coma Scale.

Pengetahuan dalam Notoatmodjo (2010) adalah hasil penginderaan manusia atau hasil tahu seseorang terhadap objek melalui indra yang dimilikinya (Mata, Hidung,Telinga, Kulit, Dan Lidah).

Berdasarkan hasil penelitian terhadap informan didapatkan hasil bahwa, pengetahuan perawat baik. Terlihat dalam pemahaman perawat ketika ditanya mengenai pengertian cedera kepala yaitu trauma didaerah kepala yang bisa disebabkan oleh terjatuh, kecelakaan lalu lintas, dan terkena bemda tumpul. Untuk pengertian Glasgow Coma Scale (GCS) pengetahuan perawat baik, yaitu pengukuran tingkat kesadaran dengan memperhatikan respons pasien yang terdiri dari Eyes (E), Motorik (M), dan Verbal (V). Untuk pengetahuan perawat dalam mengklasifikasi pasien cedera kepala berdasarkan nilai GCS, pengetahuan perawat baik klasifikasi pasien cedera kepala berdasarkan tingkat kesadaran dibagi menjadi tiga bagian yaitu ringan dengan nilai GCS antara 13-15, sedang dengan nilai GCS antara 9-12, dan cedera kepala berat dengan nilai GCS antara 38. Untuk pengetahuan perawat mengenai kapan penilaian GCS dilakukan di IGD, pemahaman perawat sudah cukup baik yaitu dilakukan pada saat awal pasien masuk, pasien di kategorikan terlebih dahulu lewat triase dibedakan menggunakan label hijau, kuning, dan merah.

Hal ini juga sejalan dengan hasil penelitian yang dilakukan oleh Indra Prasetyantoro (2013) di RSU PKU Muhammadiyah Bantul, bahwa ada Hubungan Antara Pengetahuan dengan Ketepatan Penilaian Triase dengan Tingkat Keberhasilan Penanganan Pasien Cedera Kepala.

Pada saat pelaksanaan penelitian semua informan menjelaskan jawaban yang ditanyakan oleh peneliti dengan baik maka, Peneliti berpendapat bahwa pengetahuan perawat baik, hal ini akan berpengaruh dalam pemberian pelayanan kepada pasien semakin baik pengetahuan perawat maka akan semakin baik pula pelayanan yang diberikan kepada pasien terutama pada kasus cedera kepala. Pada kasus cedera kepala pengetahuan perawat sangat berpengaruh kepada ketepatan pemberian pertolongan pasien, hal ini dikarenakan cedera kepala merupakan suatu kasus yang bersifat Urgent yang membutuhkan pertolongan yang cepat dan tepat, kemampuan perawat dalam mengklasifikasi keparahan cedera kepala akan berdampak terhadap ketepatan tindakan yang dilakukan karena beda klasifikasi beda pula penanganan yang harus diberikan.

Hasil analisa tindakan dengan kemampuan mengklasifikasi pasien cedera kepala berdasarkan nilai Glasgow Coma Scale.

Tindakan adalah suatu sikap optimis terwujud dalam suatu tindakan (Over Behaviour). Untuk mewujudkan sikap menjadi suatu perbuatan nyata diperlukan faktor pendukung atau suatu kondisi yang memungkinkan, antara lain ada fasilitas (Notoatmojo, 2010)

Dari hasil wawancara mendalam yang dilakukan kepada informan mengenai tindakan dalam penanganan pasien cedera kepala didapatkan informasi yang berbeda 3 informan memberikan informasi penanganan pasien dengan cedera kepala menggunakan prinsip standart ABC yaitu Airways (jalan Nafas) melihat apakah ada sumbatan di jalan nafas klien kemudian dilanjutkan ke Breathing (pola nafas) melihat pola nafas klien kemudian dilanjutkan dengan Circulasi (sirkulasi) memeriksa denyut nadi dan detak jantung pasien apakah ada masalah atau tidak. Sedangkan informan lainnya berpendapat berbeda penanganan yang diketahui oleh I(satu) adalah memeriksa jalan nafas (Airways) kemudian memfiksasi leher pasien, menurut I(tiga) tindakan yang dilakukan adalah tidak menggunakan alas kepala untuk pasien dan langsung memfikasi kepala pasien, sedangkan menurut I(enam) tindakan awal adalah melakukan triase pada pasien kemudian apabila memang keadaannya gawat http://jurnalilmiah.stikescitradelima.ac.id/index.php/JI Vol.4,No.1, Juli 2020 
langsung dilakukan tindakan ABC. Untuk adakah SOP di IGD tentang penanganan cedera kepala didapatkan informasi melalui wawancara mendalam bahwa semua informan memberikan informasi di IGD RSUD Depati Hamzah Kota Pangkalpinang sudah memiliki SOP mengenai penanganan pasien trauma kepala, SOP yang digunakan adalah SOP yang dibentuk tahun 2009 dan belum adanya revisi SOP sampai saat ini. Untuk sosialisasi SOP di IGD didapatkan informasi melalui wawancara mendalam bahwa 3 informan memberikan pendapat selama mereka bekerja di IGD RSUD Depati Hamzah Kota Pangkalpinang mereka tidak pernah menerima sosialisasi mengenai SOP cedera kepala, tetapi mereka menerima SOP dalam bentuk buku cetakan yang bisa dibaca di ruangan. Sedangkan menurut I(satu) sebagai staff tim akreditasi rumah sakit dia pernah menyampaikan sosialisasi terkait dengan SOP yang ada dirumah sakit ke seluruh unit ruangan pada saat sebelum proses akreditasi, sosialisasi itu dia sampaikan keliling ke setiap unit. Untuk SOP penanganan pasien cedera kepala didapatkan informasi melalui wawancara mendalam bahwa SOP (Standart Operational Prosedur) menurut 4 orang perawat memang sudah ada SOP yang mengatur tentang penanganan pasien cedera kepala dan mereka sudah melakukan tindakan sesuai dengan SOP yang ada, sedangkan menurut salah satu perawat mengatakan untuk SOP penanganan pasien cedera kepala itu sudah ada namun pada saat dilapangan SOP yang digunakan adalah SOP yang standart karena keterbatasan sarana dan fasilitas yang ada, hal ini menunjukan bahwa sarana dan fasilitas masih ada yang kurang. Sedangkan menurut dokter jaga di IGD RSUD Depati Hamzah selama dia bekerja dia tidak mengetahui mengenai kejelasan SOP yang ada dari Rumah Sakit yang dia ketahui SOP yang dilaksanakan berdasarkan dengan acuan dari ATLS (Advanced Trauma Life Support) yang bersifat nasional, hal ini menunjukan bahwa kurangnya sosialisasi tentang SOP di Ruangan.
Hal ini sejalan dengan hasil penelitian yang dilakukan oleh Sekar (2015) megenai Tindakan perawat dalam melakukan ketepatan waktu tanggap penanganan kasus cedera kepala Instalasi Gawat Darurat RSUD Dr.Moewardi Surakarta.

Pada saat pelaksanaan penelitian informan bisa menejlaskan mengenai pertanyaan yang diajukan oleh peneliti dengan baik, juga ditambah dengan adanya SOP di IGD tentang penanganan cedera kepala, maka peneliti berpendapat bahwa tindakan yang dilakukan dalam penanganan pasien cedera kepala yang dilakukan sudah cukup baik dan mereka paham serta menyadari bahwa setiap tindakan yang dilakukan harus sesuai dengan SOP (Standart Operational Prosedure) yang ada. Ketepatan pemberian tindakan sangat berpengaruh pada pasien cedera kepala untuk mengurangi dampak yang diakibatkan oleh cedera kepala itu sendiri.

\section{Hasil analisa pelatihan dengan kemampun mengklasifikasi pasien cedera kepala berdasarkan nilai Glasgow Coma Scale.}

Menurut Notoatmodjo (2010), dalam proses komunikasi kesehatan, pelatihan merupakan salah satu kegiatan pokok dalam rangka distribusi dan pelayanan produksi. Pelatihan memiliki tujuan penting untuk meningkatkan pengetahuan dan keterampilan sebagai kriteria keberhasilan proses secara keseluruhan.

Dari hasil wawancara mendalam mengenai apakah informan sudah pernah mengikuti pelatihan penanganan pasien trauma, semua informan sudah pernah mengikuti pelatihan penanganan pasien trauma, pelatihan itu meliputi pelatihan BTCLS (Basic Trauma Cardiac Life Support), PPGD (Pelatihan Penanganan Gawat Darurat), ATLS (Advance Trauma Life Support), penanganan trauma spinal dan muskuloskletal, serta penanganan trauma abdomen dan servikal. Menurut I(tujuh) semua perawat IGD sudah pernah mengikuti pelatihan gawat darurat seperti BTCLS hanya saja masih ada beberapa orang yang belum Upgrade ilmu BTCLS hal ini dikarenakan sistem penganggaran yang belum http://jurnalilmiah.stikescitradelima.ac.id/index.php/JI Vol.4,No.1, Juli 2020 
bisa mengcover semua perawat, anggran hanya bisa mengcover 2 orang perawat setiap tahunnya untuk mengikuti pelatihan BTCLS. Dari hasil wawancara mendalam mengenai apakah pelatihan yang diikuti mempengaruhi pemahaman dalam melakukan tidakan, semua informan memberikan informasi bahwa pelatihan yang diikuti sangat berpengaruh dalam memberikan ilmu untuk penanganan pasien dilapangan.

Hal ini sejalan dengan penelitian yang dilakukan oleh Annisa (2018) tentang gambaran pendidikan, pelatihan, dan lama kerja terhadap pengetahuan perawat di IGD RSUD Deli Serdang, bahwa pelatihan yang diselenggarakan kepada petugas kesehatan di IGD memberi pengaruh terhadap pengetahuan dalam memeberikan pelayanan kepada pasien di rumah sakit.

Pada saat pelaksanaan penelitian, informan mampu menjawab pertanyaan yang diajukan oleh peneliti dengan cukup baik, rata-rata perawat di IGD RSUD Depati Hamzah Kota Pangkalpinang telah lulus dari pendidikan keperawatan minimal D3 Keperawatan dan juga telah tersertifikasi standar-standar pelatihan untuk tenaga IGD. Maka peneliti berpendapat bahwa perawat disini merupakan perawat yang professional dalam melakukan tindakan karna sudah tersertifikasi oleh pelatihan-pelatihan penanganan pasien trauma seperti BTCLS (Basic Trauma Cardiac Life Support) dan ATLS (Advance Trauma Life Support).

Hasil analisa supervisi dengan kemampuan mengklasifikasi pasien cedera kepala berdasarkan nilai Glasgow Coma Scale.

Menurut Gillies (2009) Supervisi adalah mengawasi, memeriksa, meneliti yang dipandang sebagai proses yang dinamis dengan memberikan dorongan dan partisipasi dalam perkembangan perawat pelaksana.

Dari hasil wawancara terhadap informan mengenai apa yang dimaksud dengan supervisi didapatkan hasil bahwa supervisi adalah kegiatan pemantauan, motivasi, pengendalian dalam rangka mengawasi proses pemberian pelayanan keperawatan. Dari hasil wawancara terhadap informan mengenai apakah supervisi di IGD RSUD Depati Hamzah sudah berjalan maka didapatkan hasil yang sama bahwa supervisi di IGD RSUD Depati Hamzah dulunya pernah berjalan namun untuk saat ini tidak berjalan, supervisi yang dilakukan hanya bersifat situasional saja pada saat pelaksaan proses akreditasi rumah sakit yang dilaksanakan oleh semua perawat senior termasuk para kepala ruangan bukan oleh perawat supervisi, hal ini dikarenakan kurangnya SDM, manajemen, dan masalah penganggaran dirumah sakit yang terbatas.

Hal ini sejalan dengan penelitian yang dilakukan oleh Desyani (2016) tentang Hubungan Supervisi Kepala Ruangan Dengan Kepatuhan Perawat Dalam Penggunaan Alat Pelindung Diri (Handscoon) Pada Tindakan Pemasangan Infus Di RS AT-Turots AlIslamy, bahwa tidak ada pengaruh yang signifikan antara supervisi kepala ruangan dengan kepatuhan perawat dalam penggunaan alat pelindung diri (Handscoon) pada tindakan pemasangan infuse.

Pada saat pelaksanaan penelitian tidak adanya struktur organisasi pegawai di IGD mengenai adaya perawat supervisi ataupun jadwal mengenai supervisi, dan pada pelaksanaan penelitian informan mampu menjawab pertanyaan dengan baik maka peneliti berpendapat bahwa tidak ada pengaruh supervisi terhadap kemampuan perawat dalam mengklasifikasi pasien cedera kepala.

\section{SIMPULAN}

Pengetahuan perawat di IGD RSUD Depati Hamzah Kota Pangkalpinang tentang Kemampuan dalam mengklasifikasi pasien cedera kepala berdasarkan nilai GCS sudah Baik. Tindakan perawat di IGD RSUD Depati Hamzah Kota Pangkalpinang sesuai dengan SOP yang ada di Rumah Sakit. SOP yang ada merupakan SOP tahun 2009 berisikan tentang penanganan secara umum. Setiap Perawat di IGD RSUD Depati Hamzah Kota http://jurnalilmiah.stikescitradelima.ac.id/index.php/JI Vol.4,No.1, Juli 2020 
Pangkalpinang harus memiliki standart minimal sertifikasi pelatihan BTCLS, dan perawat di IGD RSUD Depati Hamzah Kota Pangkalpinang sudah pernah mengikuti pelatihan BTCLS, PPGD, dan PPGD Gel. Namun ada beberapa perawat yang belum mengupgrade sertifikasi pelatihan BTCLS. Untuk saat ini tidak ada supervisi yang dilakukan di IGD RSUD Depati Hamzah Kota Pangkalpinang. Karena terkait dengan masalah penganggaran Rumah Sakit.

\section{DAFTAR PUSTAKA}

Aprilia, Hanura (2016). Gambaran Status Fisiologis Pasien Cedera Kepala Di IGD RSUD Ulin Banjarmasin Tahun 2016. Universitas Muhammadiah Banjarmasin:Banjarmasin.

Andrew F (2010) dalam Gultom, Nelson (2016). Analisa Faktor-Faktor Yang Berhubungan Dengan Penanganan Pasien Cedera Kepala Berat Di Instalasi Gawat Darurat (IGD) RSUD Depati Hamzah Kota Pangkalpinang Tahun 2016. Skripsi strata satu, STIKES Citra Delima Bangka Belitung, Pangkalpinang.

Bhaksar (2017) dalam Ahmad, Sutanyah Imam (2017). Hubungan Score Glasgow Coma Scale (GCS) Dengan Kadar Glukosa Pada Pasien Cedera Kepala Di IGD RSUD Dr. H. Abdul Moeloek Periode Januari Sampai Maret 2017.Skripsi strata satu, Universitas Lampung,Bandar Lampung.

Campbell (1995) dalam Notoatmodjo, Soekidjo (2010).

Promosi Kesehatan : Teori \& Aplikasi. Jakarta : PT.Rineka Putra.

Dantes, Nyoman (2012). Metodelogi Penelitian. Yogyakarta: Penerbit Andi.
Ganida, Annisa P (2018). Gambaran Pendidikan, Pelatihan, Dan Lama Kerja Terhadap Pengetahuan Perawat Di IGD RSUD Deli Serdang Tahun 2017. Skripsi strata satu. Univesitas Sumatera Utara, Medan.

Hudak \& Gallo (2012). Keperawatan Kritis : Pendekatan Asuhan Holistic vol 1. Jakarta:ECG.

Junaidi (2009). Indikator Pemanfaatan Fasilitas. http://repository.ac.id. Diakses tanggal 5 April 2018

Krisanty P, M, W (2009). Asuhan Keperawatan Gawat Darurat. Trans Info Media: Jakarta.

Lawrence Green dalam Notoatmodjo, Soekidjo (2010). Promosi Kesehatan : Teori \& Aplikasi. Jakarta : PT.Rineka Putra.

Marjono, M., dan Sidartha, P. (2009). Mekanisme Trauma Susunan Saraf Pusat. Jakarta: Dian Rakyat.

Moleong (2008). Desain Penelitian Kualitatif. http://eprints.uny.ac.id/18316/5/BAB\%203\%201 0417141024.pdf. Diakses tanggal 7 April 2018.

Morton (2012) dalam Nurarif, Amin Huda, dkk (2015). Aplikasi Asuhan Keperawatan Berdasarkan Diagnosis Medis \& Nanda Nic-Noc. Yogyakarta: Mediaction.

Notoatmodjo, Soekidjo (2010). Promosi Kesehatan : Teori \& Aplikasi. Jakarta : PT.Rineka Putra.

Nurarif (2013) dalam Ahmad, Sutanyah Imam (2017). Hubungan Score Glasgow Coma Scale (GCS) Dengan Kadar Glukosa Pada Pasien Cedera http://jurnalilmiah.stikescitradelima.ac.id/index.php/JI Vol.4,No.1, Juli 2020 
Kepala Di IGD RSUD Dr. H. Abdul Moeloek

Periode Januari Sampai Maret 2017.Skripsi strata satu, Universitas Lampung,Bandar Lampung

Prasetyantoro, Indra (2013). Hubungan Ketepatan Penilaian Triase Dengan Keberhasilan Penanganan Pasien Cedera Kepala Di IGD RSU PKU Muhammadiyah Bantul. Skripsi Strata satu, STIKES Aisyiyah Yogyakarta, Yogyakarta.

Prayugo (2011) dalam Ahmad, Sutanyah Imam (2017).

Hubungan Score Glasgow Coma Scale (GCS) Dengan Kadar Glukosa Pada Pasien Cedera Kepala Di IGD RSUD Dr. H. Abdul Moeloek Periode Januari Sampai Maret 2017.Skripsi strata satu, Universitas Lampung,Bandar Lampung.

Profil data kesehatan Indonesia. 2010

Rekam Medis Rumah Sakit Bhakti Timah
Pangkalpinang. 2017

Rekam Medis Rumah Sakit Umum Daerah Depati Hamzah Kota Pangkalpinang. 2017

Riset Kesehatan Dasar. 2007

Sari, Purnama D.P.(2015). Hubungan Supervisi Kepala Ruangan Dengan Kepatuhan Perawat Dalam Penggunaan Alat Pelindung Diri (Handscoon) Pada Tindakan Pemasangan Infus Di RS AtTurots Al-Islamy. Skripsi strata satu. Universitas Aisyah Yogyakarta, Yogyakarta.

Saferi, Andra Wijaya, dkk (2013). KMB 2 Keperawatan medical bedah keperawatan dewasa dan teori dan contoh askep. Yogyakarta: Nuha Medika.

Sekar, Ruli A (2015). Peran Perawat Terhadap Waktu Tanggap Penanganan Kasus Cedera Kepala Di
Instalasi Gawat Darurat RSUD Dr.Moewardi Surakarta. Skripsi strata satu, STIKES Kusuma Husada Surakarta,Surakarta.

Smeltzer, S.C \& Bare, B.G (2002). Keperawatan medical bedah. Jakarta:ECG.

Setiadi (2007). Konsep dan Penulisan Riset Keperawatan.Yogyakarta :Graha Ilmu.

Sugiyono (2011). Metode Penelitian Kuantitatif, Kualitatif, dan R\&D.Bandung: Alvabeta.

Werner (2007). Patofisiologi Cedera Kepala menurut ahli.http://repository.usu.ac.id/bitstream/handle/1 23456789/44765/Chapter\%20II.pdf?sequence $=4$ \&isAllowed=y. diakses tanggal 6 April 2018

Wong (2009). Komplikasi Cedera Kepala Menurut Ahli. http://repository.umy.ac.id/bitstream/handle/123 456789/5820/BAB\%20II.pdf?sequence=6\&isAll owed=y. diakses tanggal 6 April 2018

http://jurnalilmiah.stikescitradelima.ac.id/index.php/JI Vol.4,No.1, Juli 2020 